Research Article

\title{
GENETIC VARIABILITY, CORRELATION AND PATH COEFFICIENT ANALYSIS OF BRINJAL
}

\author{
W.L. Konyak ${ }^{1}$, S.P. Kanaujia ${ }^{1 *}$, A. Jha ${ }^{1}$, H.P. Chaturvedi ${ }^{2}$ and A. Ananda ${ }^{1}$ \\ ${ }^{1}$ Department of Horticulture, SASRD, Nagaland University, Medziphema, Nagaland \\ ${ }^{2}$ Department of Genetics and Plant Breeding, SASRD, Nagaland University \\ Medziphema, Nagaland
}

\begin{abstract}
A field experiment was conducted during 2017-2018 for evaluating the performance of brinjal (Solanum melongena L.) genotypes under foothill condition of Nagaland following randomized block design with three replications at the experimental farm of Horticulture, SASRD, Nagaland University, Medziphema, Nagaland. Forty six brinjal genotypes viz. IIVR1, IIVR-2, IIVR- 3, IIVR- 4, IIVR-5, IIVR-6, IIVR-7, IIVR-8, IIVR-9, IIVR10, IIVR-11, IIVR-12, IIVR-13, IIVR-14, IIVR-15, IIVR-16, IIVR-17, IIVR18, IIVR-19, IIVR-20, IIVR-21, IIVR-22, IIVR-23, IIVR- 24, IIVR-25, IIVR26, IIVR-27, IIVR-28, IIVR-29, IIVR-30, IIVR-31, IIVR-32, IIVR-33, IIVR34, IIVR-35, IIVR-36, IIVR-37, IIVR-38, IIVR-39, IIVR-40, IIVR-41, IIVR42, IIVR-43, IIVR-44, IIVR-45 and Nagaland Local (check variety) were evaluated for their growth, yield, quality and genetic attributes. High phenotypic coefficient of variation, genotypic coefficient of variation and high heritability coupled with high genetic advance was found for anthocyanin content, fresh weight of fruit, number of leaves plant ${ }^{-1}$, yield plant $^{-1}$, fruit length and fruit diameter. The study on path analysis revealed that maximum positive direct effect on yield is exerted by fresh weight of fruit (1.08) and number of fruits plant ${ }^{-1}(0.407)$. Based on the experimental results, it can be concluded that, genotype IIVR-31 and IIVR-7 was proved to be potential yielder under foothill condition of Nagaland.
\end{abstract}

Keywords: Brinjal, Correlation, Path coefficient analysis, Heritability, Genetic advance

\section{INTRODUCTION}

Brinjal (Solanum melongena L), also known as eggplant and aubergine, belongs to the family Solanaceae having chromosome number $(2 n=24)$. It is an important indigenous vegetable crop of India and is considered to have originated in Indo-

* Corresponding author: spkanaujia1868@gmail.com 
Myanmar region. It is one of the most commonly grown vegetables of India. India stands $2^{\text {nd }}$ in brinjal production after China. It is grown mainly for its tender and immature fruits and has great potential as raw materials for pickle making and dehydration industries for vast domestic market as well as for export. A number of cultivars are grown throughout the country depending upon the yield, consumer's preference about the shape, colour and size. Fruit colour varies from pure white to purple, black, green and variegated in different shades. Purple colour of eggplant is due to the presence of anthocyanin pigment, while white fruit lack this pigment. Purple variety has higher copper content and polyphenol oxidase activity whereas iron and catalyse activity is highest in the green variety. Pigmented, dark-purple brinjal has more vitamin-C than those of the white skin. Amino acid content is higher in the purple variety (Kanaujia et al., 2017). The potential of brinjal as fresh vegetable is not exploited and is still insufficient to meet the domestic needs of the people. Extensive variability found in many landraces/varieties are being cultivated in different parts of India and some of the variations are so localized that their cultivation beyond the particular zone is completely unknown. Extensive collection and evaluation of germplasm to identify superior types having desirable horticultural traits, conservation and utilization of diversity are important in improvement of this crop. Genotypes of eggplant have been characterized. Both genetic and environmental factors together cause variability. Most important aspect of the genetic constitution of the breeding material is to understand the heritable variability more particularly its genetic component which has a close connection on its response to selection. High yield can be achieved by selection of characters that have high heritability coupled with genetic advance. Selection of one trait invariably affects a number of associated traits which evokes the necessity of determining interrelationships of various yield components among them and with yield. Yield is a composite character and dependent upon a number of ascribes. For an effective selection, it is essential to have the association of various attributes with yield and yield attributing characters. Estimation of correlation coefficient among the yield contributing characters is necessary to understand the direction of selection and maximize yield in the shortest period. Path co-efficient provides an efficient way of entangling direct and indirect causes of association of selection and measures the relative importance of each causal factor. Varietal performance of brinjal varies from place to place due to the varied agro-climatic conditions do not remain same for all the regions. Considering all the above mentioned facts, a pertinent need was felt to undertake an experiment on the performance of brinjal genotypes by calculating the genotypic correlations and determining the indirect effects of component characters on yield in brinjal under foothill condition of Nagaland so the present study was conducted as to identify, the best genotype suited for the agro-climatic condition of foothill of Nagaland. 


\section{MATERIALS AND METHODS}

The present was carried out in experimental cum research farm of Horticulture, School of Agricultural Sciences and Rural Development, Nagaland University, Medziphema campus, Nagaland, during November 2017 to May 2018. It is situated at an altitude of $310 \mathrm{~m}$ above mean sea level and geographically located at $25 \times 45^{\prime} 43^{\prime \prime}$ North latitude and $93 \times 53$ '04" East longitudes, in the foothills of Nagaland. The experiments comprise of forty six genotypes of brinjal viz. IIVR-1, IIVR-2, IIVR-3, IIVR- 4, IIVR-5, IIVR-6, IIVR-7, IIVR- 8, IIVR-9, IIVR-10, IIVR-11, IIVR-12, IIVR-13, IIVR-14, IIVR-15, IIVR-16, IIVR-17, IIVR-18, IIVR-19, IIVR-20, IIVR21, IIVR-22, IIVR-23, IIVR- 24, IIVR-25, IIVR-26, IIVR-27, IIVR-28, IIVR-29, IIVR-30, IIVR-31, IIVR-32, IIVR-33, IIVR-34, IIVR-35, IIVR-36, IIVR-37, IIVR38, IIVR-39, IIVR-40, IIVR-41, IIVR-42, IIVR-43, IIVR-44, IIVR-45 and Nagaland Local (check variety). All the forty-six genotypes were evaluated in randomized design block with three replications. Nursery was raised under low cost polyhouse, in which seed was sown on $15^{\text {th }}$ October, 2017. Thirty days old, healthy and uniform seedlings free from insect pests and diseases having good root system of about 10-15 $\mathrm{cm}$ height with 3-4 true leaves were transplanted to well-prepared raised beds in the main field on $15^{\text {th }}$ November. Plot size and spacing was maintained $1.8 \mathrm{~m} \mathrm{x} 1.8 \mathrm{~m}$ and $60 \mathrm{~cm} \times 60 \mathrm{~cm}$, respectively accommodating 9 plants in each plot. Recommended cultural practices and plant protection measures were followed. Observations were recorded for plant height $(\mathrm{cm})$, number of leaves plant ${ }^{-1}$, number of branches plant ${ }^{-1}$, Days taken from transplanting to $50 \%$ flowering, Days taken from flowering to fruit set, Days taken from fruit set to marketable stage, Crop duration, Fruit length $(\mathrm{cm})$, Fruit diameter $(\mathrm{cm})$, Fruit volume $(\mathrm{cc})$, Number of fruits

plant $^{-1}$, Fresh weight of the fruits, Yield plant ${ }^{-1}$, Number of seeds fruits ${ }^{-1}$ and Anthocyanin using the formula given by Ranganna (1986). The data recorded for investigation were analysed by analysis of variance (Panse and Sukhatme, 1978). Heritability (broad sense) was estimated. Genotypic and phenotypic correlation coefficients for all possible comparisons were computed (Burton, 1952). The partitioning of genotypic correlation coefficient of traits into direct and indirect effects was carried out.

\section{RESULTS AND DISCUSSION}

\section{Genetic variability, heritability and genetic advance}

The analysis of variance revealed significant differences among the genotypes for all characters studied indicating a high degree of variability in the material. However, phenotypic coefficient of variation (PCV) was always higher than their respective genotypic coefficient of variation (GCV) for all the traits indicating environmental factors influencing the characters (Table 1). It is estimated that highest genotypic and phenotypic coefficient of variation was observed for anthocyanin content (76.213 and 76.229 , respectively) followed by fruit volume (51.740 and 52.036, respectively) indicating presence of ample variation for these traits in the present material while 
Table 1. Genetic parameter for yield and yield attributing traits of 46 brinjal genotypes

\begin{tabular}{|c|c|c|c|c|c|c|c|}
\hline \multirow[b]{2}{*}{ Characters } & \multirow{2}{*}{$\begin{array}{c}\text { Mean } \\
\pm \\
\text { SEm }\end{array}$} & \multirow[b]{2}{*}{ Range } & \multicolumn{2}{|c|}{ Coefficient of variation } & \multirow{2}{*}{$\begin{array}{c}\text { Heritability } \\
(\%)\end{array}$} & \multirow{2}{*}{$\begin{array}{c}\text { Genetic } \\
\text { Advance } \\
\text { (GA) }\end{array}$} & \multirow{2}{*}{$\begin{array}{c}\text { Genetic } \\
\text { advance as in } \\
\% \text { of mean }\end{array}$} \\
\hline & & & GCV\% & $\mathrm{PCV} \%$ & & & \\
\hline Plant height $(\mathrm{cm})$ & $81.044 \pm 1.369$ & $52.5-108.73$ & 11.948 & 12.301 & 94.351 & 19.376 & 23.908 \\
\hline Number of leaves plant ${ }^{-1}$ & $82.865 \pm 5.025$ & $38-175$ & 39.375 & 40.751 & 93.358 & 64.943 & 78.372 \\
\hline $\begin{array}{l}\text { Number of branches } \\
\text { plant }^{-1}\end{array}$ & $15.574 \pm 0.345$ & $11.5-22.5$ & 13.784 & 14.308 & 92.817 & 4.261 & 27.357 \\
\hline $\begin{array}{l}\text { Days taken from } \\
\text { flowering to fruit set }\end{array}$ & $8.136 n \pm 0.444$ & $7-9.67$ & 5.342 & 10.855 & 24.222 & 0.441 & 5.416 \\
\hline $\begin{array}{l}\text { Days taken from fruit set } \\
\text { to marketable stage }\end{array}$ & $19.107 \pm 0.431$ & $15-23$ & 10.791 & 11.476 & 88.421 & 3.994 & 20.903 \\
\hline Crop duration & $148.362 \pm 3.953$ & $134.33-164.67$ & 4.486 & 6.436 & 48.580 & 9.556 & 6.441 \\
\hline Number of fruits plant ${ }^{-1}$ & $17.079 \pm 0.349$ & $9-33.83$ & 24.446 & 24.700 & 97.948 & 8.512 & 49.839 \\
\hline Fresh weight of fruit $(\mathrm{g})$ & $126.448 \pm 0.889$ & $43.17-316.17$ & 46.214 & 46.230 & 99.930 & 120.337 & 95.167 \\
\hline Number of seeds fruit ${ }^{-1}$ & $212.196 \pm 6.725$ & $60-268.33$ & 20.404 & 21.130 & 93.250 & 86.129 & 40.589 \\
\hline $\begin{array}{l}\text { Anthocyanin content (mg } \\
100 \mathrm{~g}^{-1} \text { of fruit) }\end{array}$ & $49.248 \pm 0.442$ & $5.70-153.43$ & 76.213 & 76.229 & 99.958 & 77.303 & 156.967 \\
\hline Yield $\operatorname{plot}^{-1}(\mathrm{~g})$ & $2,069.716 \pm 38.897$ & $389.33-3846.58$ & 38.825 & 39.118 & 98.504 & $1,642.903$ & 79.378 \\
\hline
\end{tabular}


lowest GCV and PCV were recorded for crop duration (4.486 and 6.436), respectively. PCV was always higher than their respective GCV. The estimates of genotypic variance, phenotypic variance and component of environmental variance were utilized to compute PCV, GCV, heritability, genetic advance and genetic advance as percentage of mean. It is not always true that high heritability would always exhibit high genetic advance. Hence, that heritability in combination with genetic advance would be more reliable for predicting effects of selection because genetic advance depends on amount of genetic variability; magnitude of masking effect of genetic expression (environmental influence), and intensity of selection. However, it is not necessary that a character showing high heritability will also exhibit high genetic advance (Johnson et al., 1955). In present study, high estimates of heritability was exhibited by anthocyanin content (99.958) followed by fresh weight of fruit (99.930) and highest genetic advance were obtained from yield plot $^{-1}$ (1642.903) followed by fruit volume (173.2401). Similar results reported by earlier investigation (Kumar, 2002). High heritability, along with high genetic advance as per cent over mean, indicated inheritance of those characters is controlled mainly by additive genes, and selection based on phenotypic performance may prove useful which will further help in improvement of their performance and these traits may be used as selection criteria in brinjal breeding program.

\section{Correlation coefficient}

It is necessary to know the correlation of yield with its economically important component for making selection in a breeding. It provides advantages of adequate selection i.e. more than one character at a time in advance generations. Correlations between character pairs are due to the linkage of genes or pleiotropy of genes. Therefore, selection of one trait influences the other linked or pleiotropically affected traits. Hence, direct selection for yield may not be effective. So, it would be necessary to have an adequate knowledge about the correlation studies in the plant improvement because they are helpful in making an effective selection. In general, the magnitude of genotypic correlation coefficient was lesser than the corresponding values of the phenotypic correlation coefficient. This indicates that the expressions of character associations had been influenced by the environment and the apparent association may not be largely due to genetic reason. The difference between genotypic and phenotypic correlation was low, indicating that the environmental effects did not have much influence on these characters. The current study revealed that at genotypic level, fresh weight of fruit (0.894), fruit volume (0.840), number of branches (0.622) and plant height (0.495) exhibited significant positive correlation with yield plant ${ }^{-1}$. Maximum significant negative correlation with yield plant $^{-1}$ was revealed in anthocyanin content (-0.273) as shown in Table 3. The results were in close harmony with Patel et al. (2015). The higher magnitude of positive, direct

effects, for number of fruitsplant ${ }^{-1}$, fruit length and marketable yield plant ${ }^{-1}$ on total yield plant $^{-1}$ indicates true, positive and significant association (Table 2). 
Table 2. Genotypic correlation among fifteen yield and yield attributing traits of brinjal

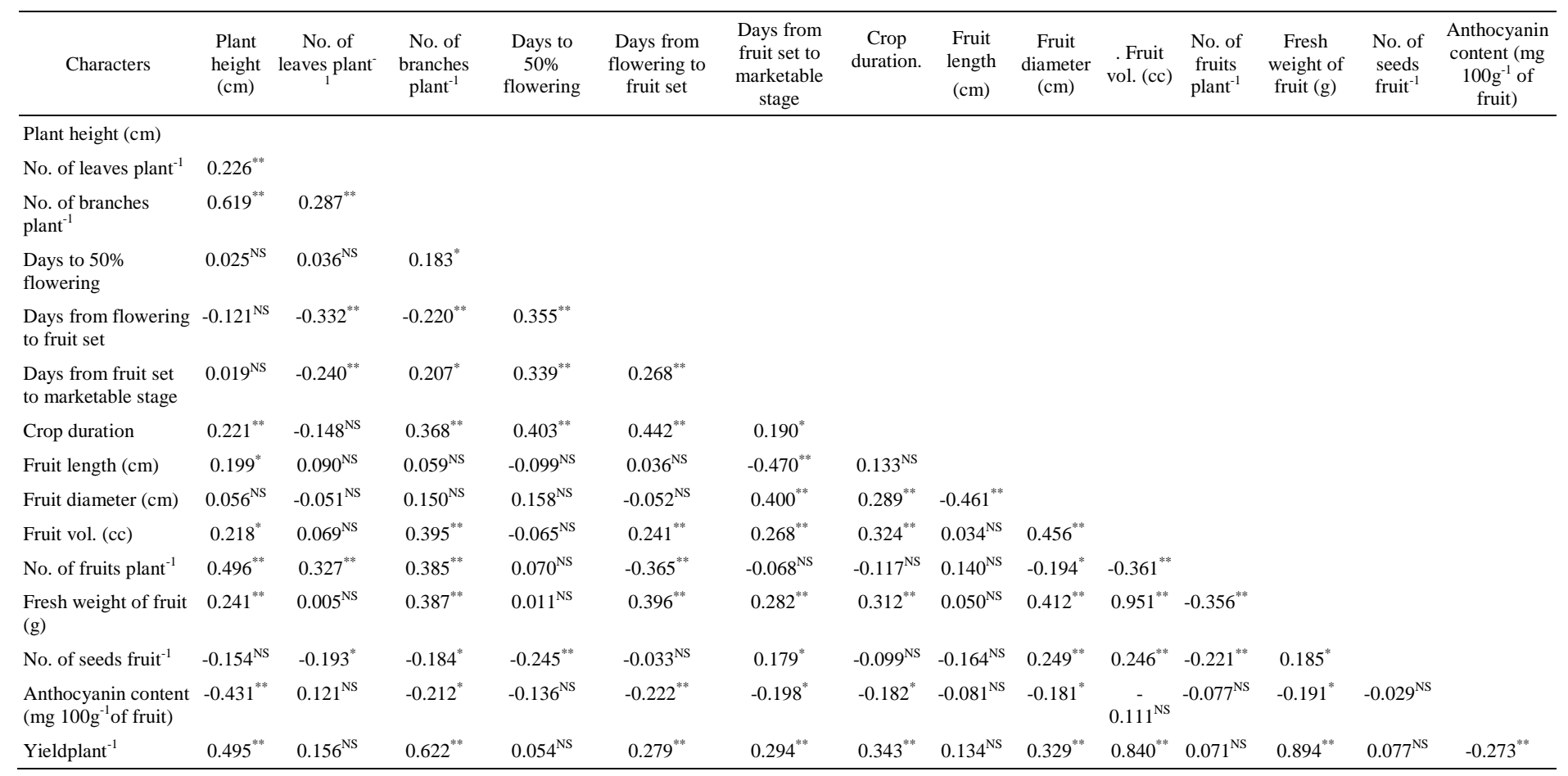

Note: * and **: indicated significant at $5 \%$ and $1 \%$ level of probability, respectively. NS indicates non-significant. 
Table 3. Direct (diagonal) and indirect effects of yield components at genotypic level in brinjal genotypes

\begin{tabular}{|c|c|c|c|c|c|c|c|c|c|c|c|c|c|c|c|}
\hline Characters & $\begin{array}{l}\text { Plant } \\
\text { height } \\
(\mathrm{cm})\end{array}$ & $\begin{array}{l}\text { No. of } \\
\text { leaves } \\
\text { plant }^{-1}\end{array}$ & $\begin{array}{l}\text { No. of } \\
\text { branches } \\
\text { plant }^{-1}\end{array}$ & $\begin{array}{c}\text { Days to } \\
50 \% \\
\text { flowering }\end{array}$ & $\begin{array}{l}\text { Days } \\
\text { from } \\
\text { flowering } \\
\text { to fruit } \\
\text { set }\end{array}$ & $\begin{array}{c}\text { Days from } \\
\text { fruit set to } \\
\text { marketabl } \\
\text { e stage }\end{array}$ & $\begin{array}{l}\text { Crop } \\
\text { duration }\end{array}$ & $\begin{array}{l}\text { Fruit } \\
\text { length } \\
(\mathrm{cm})\end{array}$ & $\begin{array}{c}\text { Fruit } \\
\text { diameter } \\
(\mathrm{cm})\end{array}$ & $\begin{array}{l}\text {. Fruit } \\
\text { vol. (cc) }\end{array}$ & $\begin{array}{c}\text { No. of } \\
\text { fruits plant }\end{array}$ & $\begin{array}{l}\text { Fresh } \\
\text { weight } \\
\text { of fruit } \\
(\mathrm{g})\end{array}$ & $\begin{array}{l}\text { No. of } \\
\text { seeds } \\
\text { fruit }^{-1}\end{array}$ & $\begin{array}{c}\text { Anthocyani } \\
\mathrm{n} \text { content } \\
\left(\mathrm{mg} 100 \mathrm{~g}^{-1}\right. \\
\text { of fruit })\end{array}$ & $\begin{array}{l}\text { Genotypic } \\
\text { correlation } \\
\text { with yield }\end{array}$ \\
\hline No. of leaves plant ${ }^{-1}$ & -0.00508 & 0.04775 & 0.01061 & -0.00205 & 0.00377 & -0.01548 & -0.01492 & 0.00088 & 0.00247 & -0.00596 & 0.13324 & 0.00498 & 0.00047 & -0.00479 & $0.156^{\mathrm{NS}}$ \\
\hline $\begin{array}{l}\text { No. of branches } \\
\text { plant }^{-1}\end{array}$ & -0.01394 & 0.01369 & 0.03699 & -0.01034 & 0.00249 & 0.01331 & 0.03718 & 0.00059 & -0.00719 & -0.03404 & 0.15664 & 0.41761 & 0.00044 & 0.00841 & $0.622^{* *}$ \\
\hline $\begin{array}{l}\text { Days from flowering } \\
\text { to fruit set. }\end{array}$ & 0.00273 & -0.01586 & -0.00813 & -0.02009 & -0.01133 & 0.01727 & 0.04466 & 0.00036 & 0.00249 & -0.02077 & -0.14866 & 0.42712 & 0.00008 & 0.00881 & $0.279^{* *}$ \\
\hline $\begin{array}{l}\text { Days from fruit set } \\
\text { to marketable stage }\end{array}$ & -0.00043 & -0.01148 & 0.00765 & -0.01919 & -0.00304 & 0.06439 & 0.01914 & -0.00463 & -0.01924 & -0.02310 & -0.02762 & 0.30421 & -0.00043 & 0.00785 & $0.294^{* *}$ \\
\hline Crop duration & -0.00498 & -0.00706 & 0.01362 & -0.02281 & -0.00501 & 0.01221 & 0.10095 & 0.00131 & -0.01391 & -0.02792 & -0.04767 & 0.33648 & 0.00024 & 0.00725 & $0.343^{* *}$ \\
\hline Fruit length $(\mathrm{cm})$ & -0.00449 & 0.00428 & 0.00220 & 0.00560 & -0.00041 & -0.03028 & 0.01342 & 0.00985 & 0.02216 & -0.00290 & 0.05696 & 0.05369 & 0.00040 & 0.00323 & $0.134^{\mathrm{NS}}$ \\
\hline $\begin{array}{l}\text { Fresh weight of fruit } \\
(\mathrm{g})\end{array}$ & -0.00543 & 0.00022 & 0.01431 & -0.00064 & -0.00448 & 0.01815 & 0.03146 & 0.00049 & -0.01981 & -0.08210 & -0.14489 & 1.07959 & -0.00045 & 0.00760 & $0.894^{* *}$ \\
\hline $\begin{array}{l}\text { Number of seeds } \\
\text { fruit }^{-1}\end{array}$ & 0.00347 & -0.00922 & -0.00681 & 0.01388 & 0.00037 & 0.01152 & -0.01004 & -0.00162 & -0.01197 & -0.02119 & -0.08981 & 0.20010 & -0.00242 & 0.00115 & $0.077^{\mathrm{NS}}$ \\
\hline $\begin{array}{l}\text { Anthocyanin content } \\
\text { (mg } 100 \mathrm{~g}^{-1} \text { of fruit) }\end{array}$ & 0.00970 & 0.00576 & -0.00783 & 0.00770 & 0.00251 & -0.01273 & -0.01841 & -0.00080 & 0.00868 & 0.00961 & -0.03121 & -0.20665 & 0.00007 & -0.03973 & $-0.273^{* *}$ \\
\hline
\end{tabular}




\section{Path coefficient analysis}

Path coefficient analysis has been carried out to analyse the direct and indirect effect of causal factors which affect the yield. It is simply standardized partial regression coefficient which splits the correlation coefficient into the measures of the direct and indirect effects of a set of independent variables on the dependent variable. The present study on path coefficient analysis revealed that the maximum positive direct effect on yield plant ${ }^{-1}$ was exhibited by fresh weight of fruit (1.0795) followed by number of fruit plant $^{-1}(0.40709)$ and crop duration (0.10095). However, traits like days from fruit set to marketable stage, number of leaves plant ${ }^{-1}$, number of branches plant $^{-1}$ and fruit length also exerted positive direct yield effect and exhibited significant positive correlation with yield plot $^{-1}$ indicating a true relationship between the traits. High order of negative direct effect on yield plant ${ }^{-1}$ was exerted by fruit volume $(-0.08629)$ followed by days to $50 \%$ flowering $(-0.05664)$ and anthocyanin content (-0.03973). Similar observations were also recorded by past researchers (Shende et al., 2015; Patel et al., 2015; Kumar and Arumugam, 2016). The residual effect was low (0.016) indicating that traits under study are sufficient to account for variability as shown in Table 3 . Thus material studied would help in designing the selection methodology which further be used in breeding program. Hence, purposeful and balanced selection based on these particular characters would be rewarding for improvement in brinjal genotypes and thereby confirmed the past findings (Flory et al., 2017; Kanaujia et al., 2018).

\section{CONCLUSION}

The present study has shown significant variability and diversity in the brinjal germplasm for yield and yield related characters. From the results based on growth, yield and quality it can be concluded that the genotypes IIVR-31 and IIVR-7 was found promising and on the basis of genetic variability studies suggested that while selection emphasis should be given on fresh weight of fruit, number of fruits plant ${ }^{-1}$, crop duration, number of leaves and number of branches for increasing yield and crop improvement. An overall observation of qualitative and quantitative characters it is suggested that these genotypes IIVR-31 and IIVR-7 need to be critically analyzed as it performed much better under foothill condition of Nagaland. It would therefore, be rewarding to lay stress on these characters in hybridization program for further improvement of yield and related characters in brinjal.

\section{ACKNOWLEDGEMENT}

The authors are thankful to Project coordinator, AICRP (vegetable crops), IIVR, Varanasi for providing research materials and financial assistance. 


\section{REFERENCES}

Burton, G.W. and DeVane, E.H. (1952). Estimating heritability in tall fesue (Feslucaarundinacea) from replicated clonal material. Agronomy Journal, 45: 418-481.

Flory, R., Kanaujia, S.P., Sema, A., Maiti, C.S. and Chaturvedi, H.P. (2017). Genetic diversity analysis in tomato (Solanum lycopersicum) genotypes. Indian Research journal of Genetic and Biotechnology, 9(3): 421-426.

Johanson, H.W., Robinson, H.F. and Comstock, R.E. (1955). Estimates of genetic and environmental variability of soybean. Agronomy Journal, 47: 314-318.

Kanaujia S.P., Devi, O.B., Jha, A., Ananda, A. and Shah, P. (2018). Genetic variability, characters association and path coefficient analysis of brinjal (Solanum melongena) Genotypes Under Foothill Condition of Nagaland. Biotech Today, 8(2): 85-91.

Kanaujia, S.P., Maiti, C.S. and Narayan, R. (2017). Brinjal. Text book of vegetable production. New Delhi: Today and Tomorrow's Printers and Publishers. Pp. 19-28.

Kumar R.S. and Arumugam, T. (2016). Gene action in eggplant landraces and hybrids for yield and Quality Trait. Indian Journal of Farm Sciences, 6(1): 79-89.

Panse, V.G. and Sukhatme, P.V. (1978). Statistical methods for agricultural workers. New Delhi: ICAR. Pp. 97-151.

Patel, K., Patel, N.B., Patel, A., Rathod, H. and Patel, D. (2015). Study of variability, correlation and path analysis in brinjal (Solanum melongena L.). An International Quarterly Journal of Life Science, 10(4): 2037- 2042.

Ranganna, S. (1986). Manual of analysis of fruits and vegetables products. Tata McGraw Hill Co. Pvt. Ltd., New Delhi.

Shende, R.A., Desai, S.S. and Lachyan, S.T. (2015). Genetic variability and response to selection in brinjal (Solanummelongena L.). Indian Journal of Current Research, 7(10): 21545-21547.

Singh, D.K. and Kumar, R. (2002). Studies on the genetic variability in bottle gourd. Progressive Horticulture, 34(1): 99-101. 